\title{
INCREASING THE STUDENTS' SKILL IN READING NARRATIVE TEXT BY USING KNOW-WANT-LEARNED STRATEGY AT THE EIGHT GRADE STUDENTS OF JUNIOR HIGH SCHOOL 3 PALEMBANG
}

\author{
Etty Pratiwi, Dewi Kartika Sari \\ ettypratiwi1998@gmail.com, ekamarza@gmail.com \\ PGRI University of Palembang
}

\begin{abstract}
The aim of this research was to increase the students' skill in reading narrative text by using Know-Want-Learned strategy at the eight grade students of Junior High School 3 Palembang. This research of this study was conducted by using classroom action research. The data used in this research are the result the pre-test to know the improvement of students in reading narrative text. The mean of the pre-test was 64,5 . The mean of the first cycle was 84,85 , it indicated that the scores and the mean in first cycle were better than the pre-test. The percentage of students who got point 75 or more there was also grew up. In the pre-test, there was 10 students $(25 \%)$ who passed or got score up to 75 . In the post-test of cycle I the students who got point 75 or more there was 40 $(100 \%)$ and the increasing was about $75 \%$. In other words, the students' skill in reading narrative text improved and became well in the first meeting to the next meeting. For the hyphothesis testing used t-test formula from the compilation, it could be seen that coefficient of it could be seen that coefficient of tobserved $(16,72)>t_{\text {table }}(0,316)$. Thus, alternative hyphothesis $(\mathrm{Ha})$ could be received. Based on the research, It could be get that using Know-Want-Learned (KWL) Strategy could increase the students' skill in reading narrative text.
\end{abstract}

Keywords: Reading Skill, Narrative Text, Know-Want-Learned Strategy

\section{Introduction}

Reading is one of the receptive language skills that is very important to be mastered in order to get important information. By being able to read, the students can get many new vocabularies from the text. They are able to learn grammatical aspect from what they read. Reading has important function in guiding the students to think critically related to the content of the text. They are some aspects that influence reading that consist of internal and external aspects.

Internal aspects include of intrinsic motivation, interest in reading, reading habit, and learning style. Meanwhile, external aspects include of learning media, learning strategy, and external motivation from family members, classmate, and society.

However, reading skill is not easy.
There are many problems in reading skill faced by the students. It is difficult for the students to understand the content of the text because they do not know the meaning of the words. In addition, they are difficult in reading the text because they have limited vocabulary and low grammar mastery.

Using reading in narrative text make the students to be able to get the knowledge and to understand the context from that has been explained in the text. By reading, the students are expected can answer the questions that consist of the text and the students are be able to comprehend the text as a whole.

Jaya et al (2016) In reality the students are not be able to comprehend the narrative text as a whole. They thought that they should open dictionary to translate word by word into Indonesia to know the content 


\section{ESTEEM JOURNAL OF ENGLISH STUDY PROGRAME \\ P-ISSN 2622-9323 \\ E-ISSN 2622-2213}

of reading narrative text. The students can not answer the questions that consist of the narrative text. They are not be able to get knowledge and to understand the content from that has been explained in the narrative text.

There are many factors that cause the low skill in reading narrative text. There are some factors, those factors comes from internal and external. Internal factors are such as : IQ (Intelligence Quotient), motivation, proclivity, talent etc. External factors are environment, such as : teacher, parents, friends, facility, media, including strategy. Strategy can cause the students' low skill in reading narrative text, Jaya et al (2017) strategy can make teaching- learning in reading more effective to increase the students' knowledge.

There are many strategies that can be applied to improve the students' achievement in reading narrative text including KWL (Know-Want-Learned) strategy. Jones stated KWL is a column chart that helps students, during and after components of reading a text. KWL strategy for the three basic cognitive steps required: accessing what I Know, determining what I Want to learn, and recalling what I did Learn as a result of reading. To facilitate both the group process and to instill in students the concreteness of the steps, we developed a worksheet that each child uses during the thinking reading process.

KWL Strategy is useful to help the students to find out the specific information from narrative text after read it. Under this strategy, the teacher activities in the class by asking them what they already Know, the students collaborating as a classroom unit or within small groups, set goals specifying what they Want to learn; and after reading, students discuss what they have Learned. Through this learning strategies, students can improve their reading skills can be easy to find the main idea of a reading text. A worksheet is given to every student that includes columns for each of these three integrated activities.

KWL strategy can increase students' skill in reading because this strategy focused on help students' to build up meaning from they have read and also help them to examine their progress toward their goals. This strategy is aimed to be a good exercise for a study of group or a class in reading narrative text. It means KWL strategy is useful to help the students to find out the specific information from narrative text after read it.

\section{Research methods}

This study was categorized into action research. It is a method for solving the problems of teaching objectively and systematically. The aim of this study was to show the process of increasing of the students' reading comprehension. In this study, the researchers collaborated with all of the other research team members.

Burns asserts that action research is a part of broad movement that has been going on in education generally for some time. According to in Singh action research is a process for studying problem by partsowners scientifically to take decision for improving their current practice.

Classroom Action Research is the action research that implemented in the classroom when learning. The purpose of classroom action research for corrected or improved.

Moreover, Kemmis and Taggart in Burns define that action research typically involves four broad phase in a cycle of research, the first cycle may become a continuing or iterative, spiral of cycles which recur until the action researcher has achieved a satisfactory outcome and feel it is time to stop. It means that second cycle is not necessary to be continued if the class means score at the first cycle is satisfying or there are significance progresses in first cycle.

Based on all explanation above, statement of Kemmis and Taggart is more 


\section{ESTEEM JOURNAL OF ENGLISH STUDY PROGRAME P-ISSN 2622-9323 \\ E-ISSN 2622-2213}

relevant to the researcher's intention. Therefore, in this research, the researchers used the cyclical model based on kemmis and taggart.

There are four road phases in a cycle of research can be seen following figure : (1) Planning is concerned action or arrangement of doing something. It must be prospective the action, and must be forward looking. Planning means the reflection of the action will be done. (2) Action is careful and thoughtful variation of practice. It is the implementation of planning. Action is thus fluid and dynamic, requiring instant decision about what is to be done and exercise of practical judgment appropriate to students' condition. The implementation od action plans will assume the character of a material, social, and political struggle toward improvement. (3) Observation is used to establish objective data concerning what goes in most classroom, or in a range of classrooms. It is investigation about the various kinds of move (structuring classroom activity, soliciting response) which teachers use in their teaching. It is done when the classroom action research is going on by the collaborator. Observation for shadow the achievement of reflection. (4) Reflection recalls action as it has been recorded in observation. Reflection has an evaluative aspect that asks action researchers to weight their experience, to judge whether effect are desirable. Reflection is the evaluation of actions that has been done. The reflection is done to recover the problem that is happened in the previous cycle.

The process of doing treatment was done in two cycles that consist of six meetings. The first cycle consist of four phases namely planning, action, observation and reflection.

\section{The First Cycle}

In the first cycle, the researchers observed the situation of teaching- learning process in the class sample, make an oral interview with students in order to know their opinions about Learning English especially in reading activity, and identify the student's problem in reading process.

a. Planning

Planning is arrangement for doing something. In this phases there had been many activities organized that had been done in action phases related to identify problem, such as: (1) Preparing lesson plans. (2) Preparing reading texts and the tests for each meeting. (3) Preparing the facilities and media that had be used. (4) Preparing questionnaire sheet and observation sheet for the students. (5) Planning and designing the application of teaching reading by using KWL chart.

b. Action

Action is the process of doing. Action is the implementation of planning. Everything that has been planned had been done in five meetings for the first cycle. Those activities had been done as the following : (1) Teacher gave the apperception to active the students' prior knowledge. (2) The researchers motivated the students.

(3) The researchers tought the students the goal of the activity. (4) The researchers gave the students one topic of narrative text and ask them to make a KWL chart based on the topic given. (5) After filling rhe $\mathrm{K}$ and $\mathrm{W}$ session, the teacher asked the students to read the whole text and try to find the new information related to what they have in the $\mathrm{W}$ session, the information should be put in the L session. (6) After completing the KWL chart, researchers leaded the students to have a discussion and share each other about their chart. A misconception should be clarified. (7) Twenty minutes before the time up, teacher gave individual test for the students. (8) Students answered the questions which are related to the narrative text, text organization (orientation, complication, and resolution). (9) Teacher evaluated the whole activity.

c. Observation 


\section{ESTEEM JOURNAL OF ENGLISH STUDY PROGRAME \\ P-ISSN 2622-9323 \\ E-ISSN 2622-2213}

Observation had been done when the classroom action research had gone. Observation is phase to record everything happens during teaching-learning process including the effects of the actions. The purposes of observation is to find out the information of action, such as students' attitudes, behaviors, and activities while giving action even the obstacles that happened in observer's book. The observer observed whole teaching learning process in the classroom. The observer is to see how the teaching and learning design points have been implemented as a whole or not, then whether the result is good or not. This step provided the observer the data as the result of the respond of the step in acting. This observation proved the action.

\section{d. Reflection}

Reflection is as the evaluation of the action which has been done. The teacher should make it as the feedback of the running of the cycle. Through doing the reflection, the researchers reflected on everything done and make conclusion as a whole.

The conclusion concerns with the process and the result. Whatever the weakness or the strength found had be listed on so that the researchers could evaluate what need to be evaluated and improve what need to be improved if there is no incresing in the first cycle. Therefore it must be continue to the second cycles.

2. The Second Cycle

a. Planning

The researchers had planned the implementation of lesson plan that related to the cycle I that had evaluated and developed for the action of cycle II

b. Action

In this section, the researchers did the action that looked on the reflection that had evaluated and revised.

c. Observation

In this section, the collaborator checked the observation sheet making a cheklist in the observation format. The researchers did interview to know the classroom and the actions that happened in the classroom.

d. Reflection

In this section, the researchers reflected the evaluation of teaching learning process and evaluated what had been done in the cycle II.

\section{Research Results And Discussion}

Based on the result of the quantitative data, the result showed that the students increased their skill in reading narrative text. The students' score was getting better from the first meeting until the third meeting in the test. It was proven by the students' mean score which increased in each meeting. The mean of the students' score in the pre-test was 64,5. It was low because only 10 students who got the score 75 and more. The mean of the students' score in the post-test of cycle I was 84,85 . It was higher than the pretest of cycle I. The increasing of the students' mean score from the pre-test of cycle I to the post-test of cycle I was 20,35.

Then, the percentage of the students who got the score 75 and more in the pre-test was ten of forty students (25\%). The percentage of the students' who got the score 75 and more in the post-test of cycle I was forty of forty students $(100 \%)$. The increasing of the competent students percentage from the pre-test to the post-test cycle I was $75 \%$. It indicated that the increasing of the students' skill in reading in narrative text was significant.

Based on the result of the qualitative data which was taken from the observation sheet an interview report, it was found that the class ran effectively. The students paid attention to the teacher during the teaching learning process. They were also spirit in reading and enjoying the learning process. Then, it can be said that the qualitative data was also showed the increasing of the teacher's and the students' activities during the teaching learning process. It indicated 


\section{ESTEEM JOURNAL OF ENGLISH STUDY PROGRAME \\ P-ISSN 2622-9323 \\ E-ISSN 2622-2213}

that the application of KWL startegy could motivate the students became more enthusiastic in learning reading in narrative text.

\section{Interpretations}

From the explanation above, it could be concluded that the result of the research showed that the application of KWL strategy could increasing the students' skill reading in narrative text. It could be proven by the quantitative data which showed the students' score got better from the pre-test to the posttest of cycle I. It also could be proven by the qualitative data which showed that the teacher got better in controlling the class and the students' were more active and enthusiastic learning reading in narrative text.

\section{Conclusion}

Based on the result of the research, it could be concluded that:

1. In the preliminary study, quantitatively showed that score of the students was 2580 and the mean of the students' score 64,5 . The percentage of the students' score of the test was 10 students who passed or got score up to 75 , it was only $25 \%$. There was 30 students who got failed. Qualitatively showed from the result of observation and the interview, it can be proven that the students' achievement in reading was not good yet and low in reading test of the pre-test.

2. In the first cycle, quantitatively showed that the total score of the students was 3394 and the mean of the students' score of the test was 84,85 . The percentage of the students' score of the test was 40 students who passed and got score 75 or up to 75 it was $100 \%$. Qualitatively, showed from the result of interview, it can be concluded that the students felt better, easier, and interesting to learn reading narrative text by using $\mathrm{KWL}$ strategy.
3. Based on the data analysis, the result of the research showed the improvement of the students' achievement reading in narrative text by using KWL strategy.

\section{Suggestion}

The result of this research showed that the application of KWL strategy could improve the students' achievement reading in narrative text. Therefore the following suggestions were offered:

1. For the Principal of Junior High School of 3 Palembang, it is useful to make an instructional concept in English subject especially in teaching reading in narrative text by using KWL strategy.

2 For the English teacher, it is useful to apply KWL strategy as one of the alternative way in teaching reading in narrative text to make a variation in teaching reading in narrative text so that the students do not get bored in learning English especially in reading in narrative text.

3. For the students, they feel more interest and motivated in learning reading in narrative text because they can enrich their knowled ge and helps stimulate their thoughts in reading skill.

4. For the other researchers, it is very useful as the information in conducting in depth research which is related to this research.

\section{References}

Alderson, J. Charles. (2000). Assessing Reading: Cambridge University. Anderson, Neil. Nunan, David (ed). (2003). Practical English Language Teaching. New York: McGraw-Hill.

Andrew, K, Shenton. (2004). Strategies for Ensuring Trustworthiness in Qualitative Research Projects. Education for Information: Northumbria University. 


\section{ESTEEM JOURNAL OF ENGLISH STUDY PROGRAME \\ P-ISSN 2622-9323 \\ E-ISSN 2622-2213}

Anne, Burns. (2010). Doing Action Research in English Language Teaching: a guide for practitioners. London \& New York: Routledge.

Brown, H. D. (2004). Language

Assessment: Principle and Classroom

Practices.

New York: Longman, Pearson

Education.

Brown, H.D. (2000). Principles of Language Learning and Teaching (Fourth Edition) New York: Pearson Education.

Drajat, S Untung. accessed on Tuesday, $24^{\text {th }}$ January

2017. Kerangka

Pembelajaran.http://untungsdrajat.blo gspot.com/2008/08/lampirankerangka-pembelajaran-abb.html).

Grabe, W And Stoller, F.L .2002. Teaching and Researching Reading ( First Edition).Edinburg : Person Educated Limited.

Kemmis, S \& McTaggart, R. (1988). The Action Research Planner. Burns. Masganti. (2011). Metodologi Penelitian Pendidikan Islam. Medan: IAIN PRESS. Nugrahani,Arifiyati. Fernando. 2006. Language To Use English. Jakarta: Piranti Darma Kalokatama.

Jaya, A. Habibi, A. 2016. Fishbowl Technique and Learning Interest Effects on Speaking Achievement of SMK Sembawa. Jambi-English Language Teaching. 1(1)

Jaya, A. Hermansyah, Mortini, A. 2018. The Effect of Crawford Series Teaching (CST) on the Students'
Writing Achievement. ESTEEM: Journal of English Study Program. 1(1).

Nunan, David. (2013). Practical English Language Teaching. New York: McCraw Hill.

Ogle, D, M. (1986). K-W-L: A Teaching Model that Develops Active Reading of Expository Text, Readig Teacher. New York: The Guilford.

Peregoy, S \& Boyle, O. (2001). Reading, Writing \& Learning in ESL. New York: Addision Wesley Longman.

Pradiyono. (2007). Pasti Bisa! Teaching Genre-Based Wrtiting. Yogyakarta: Andi.

R, Jones. (2007). Strategies For Reading Comprehension. [on line]. Accessed on 03 January 2017, Tersedia: http: //www.readingquest.org/strat/kwl.htm 1.

Ros, C and Vaughn, S. (2002) Strategies for Teaching Students with Learningand Behavior Problems. USA: Rinehart and Winston, Inc.

S. Y, \& E. G, Guba. (1985), Naturalistic inquiry. Newbury Park: CA Sage. Sanjaya, Wina. (2010). Penelitian Tindakan Kelas. Jakarta: Kencana Prenada Media Group.

Shakir, Muhammad Habib, The Qur'an Translation Muhammad Habib Shakir English Only (Tharike Tarsile Qur'an)

Singh, K Yogesh. (2006). Fundamental of Research Methodology and Statistics. New Delhi: APH. 
Travers, P, John. 1970. Fundamental of education psychology. Pensylvania: International Textbook Company.

Vault De Gigi . Establishing Trustworthiness, Accessed on Sunday, $15^{\text {th }} \quad$ January 2017. (Http://thebalance.com/establishing- trustworthiness-in-qualitativeresearch).

Willis. M. D, Judy. (2008). Teaching the Brain to read.Association for Supervision and Curriculum Development. Alexandria: Virginia USA. 